\section{Decreased astrocytic GFAP expression in streptozotocin- induced diabetes after gliotoxic lesion in the rat brainstem}

\author{
Expressão astrocitária diminuída de GFAP no diabetes induzido por \\ estreptozotocina após lesão gliotóxica no tronco encefálico de ratos
}

Eduardo Fernandes Bondan 1,2, Maria de Fátima Monteiro Martins ${ }^{1,2}$, Flávio Cesar Viani ${ }^{2}$

\begin{abstract}
Objective: The aim of this study was to evaluate the effect of diabetic hyperglycemia on astrocyte function, estimated by means of glial fibrillary acidic protein - GFAP - immunohistochemical expression. Materials and methods: Adult male rats received a single intravenous injection of streptozotocin $(50 \mathrm{mg} / \mathrm{kg}$ ) and were submitted 10 days later to a single injection of 10 microlitres $0.1 \%$ EB solution or $0.9 \%$ saline solution into the cisterna pontis. Ten microliters of $0.1 \%$ EB or $0.9 \%$ saline solution were also injected in non-diabetic rats. Animals were anesthetized and perfused through the heart 15 and 31 days after EB or saline injection, and brainstem sections were collected for ultrastructural analysis and GFAP immunohistochemical staining. Results: The GFAP brown-stained areas were evaluated by colorimetry using a computerized image analysis system and the results have shown that diabetes hindered the increase of GFAP astrocyte expression in the EB-injected group compared to non-diabetic animals. However, diabetes did not affect GFAP response in the saline-injected group or in control animals. Conclusion: Streptozotocin-induced diabetic condition reduced astrocytic GFAP expression following gliotoxic injury. Arq Bras Endocrinol Metab. 2013;57(6):431-6
\end{abstract}

\section{Keywords}

Astrocytes; GFAP; central nervous system; diabetes mellitus; ethidium bromide

\section{RESUMO}

Objetivo: O objetivo deste estudo foi avaliar o efeito da hiperglicemia na função astrocitária, estimada pela expressão imuno-histoquímica da proteína glial fibrilar ácida - GFAP. Materiais e métodos: Ratos machos adultos receberam uma injeção intravenosa única de estreptozotocina (50 mg/kg) e foram submetidos, 10 dias após, à injeção de 10 microlitros de solução de BE $0,1 \%$ ou de salina $0,9 \%$ na cisterna pontina. Dez microlitros de BE $0,1 \%$ ou salina $0,9 \%$ foram também injetados em ratos não diabéticos. Os animais foram anestesiados e perfundidos por via intracardíaca aos 15 e 31 dias pós-injeção de BE ou salina, e amostras de tronco encefálico foram coletadas para estudo ultraestrutural e análise imuno-histoquímica para a GFAP. Resultados: Utilizando um sistema computadorizado de análise de imagens, os resultados das áreas coradas em marrom pela GFAP, medidas por colorimetria, mostram que o diabetes reduziu o aumento de expressão dessa proteína no grupo injetado com BE em comparação aos animais não diabéticos, mas não alterou a resposta no grupo injetado com salina ou nos controles diabéticos. Conclusão: 0 estado diabético induzido pela estreptozotocina reduziu a expressão astrocitária de GFAP após dano gliotóxico. Arq Bras Endocrinol Metab. 2013;57(6):431-6

\section{Descritores}

Astrócitos; GFAP; sistema nervoso central; diabetes melito; brometo de etídio
Post-Graduate Program in Environmental and Experimental Pathology, Universidade Paulista, São Paulo, SP, Brazil ${ }^{2}$ Veterinary Medicine Department, Universidade Cruzeiro do Sul, São Paulo, SP, Brazil

Correspondence to: Eduardo Fernandes Bondan Rua Caconde, 125/51 01425-011 - São Paulo, SP, Brasil bondan@uol.com.br

Received on Jan/15/2013 Accepted on Apr/2/2013 


\section{INTRODUCTION}

$\mathrm{I}$ $\mathrm{t}$ is widely described that ethidium bromide (EB) injection in the white matter of the central nervous system (CNS) acts like a gliotoxin, causing local oligodendroglial and astrocytic death, with consequent demyelination (although naked axons remain preserved), blood-brain barrier disruption, and Schwann cell invasion due to the glia limitans breakdown (1-5). Surviving astrocytes present vigorous reaction around the injury site with increased immunorreactivity to the specific cell marker, glial fibrillary acidic protein (GFAP), and reexpression of vimentin (VIM) (5). Hyperglycemia found in diabetes mellitus is known to cause well-characterized morphological and functional changes in peripheral neurons and Schwann cells (6). Much less is known about the effects of hyperglycemia on CNS cells, mainly on glia. It is recognized that diabetes exacerbates astrocytic $(7,8)$ and neuronal $(9,10)$ damage induced by ischemia and reperfusion. On the other hand, insulin treatment prevents diabetes-induced alterations in astrocyte glutamate uptake and reverts the decreased GFAP expression in rats at 4 and 8 weeks of diabetes duration (11). Glial modifications were clearly pointed out in some studies $(12,13)$ using streptozotocin-diabetic rats after the injection of EB, with marked delay on macrophagic scavenging activity of myelin debris, on oligodendrocyte and Schwann cell remyelination (12), as well as on blood-brain barrier repair (13), although astrocytic response was not properly investigated and compared between diabetic and non-diabetic animals. In such context, the aim of the present investigation was to evaluate the effect of diabetic hyperglycemia on astrocyte function (estimated by means of GFAP immunohistochemical expression) in rats injected or not with EB in the brainstem, serving as normal homeostatic regulators in the neural microenvironment or as reactive and repairing cells after injury.

\section{MATERIALS AND METHODS}

This experiment was approved by the Ethics Commission of Universidade Paulista (protocol number 002/09). Adult male Wistar rats, 3 to 4 months old, were used, from which some received, after 12 hours of fasting, a single injection of streptozotocin $(50 \mathrm{mg} / \mathrm{kg}$, Sigma) in $0.01 \mathrm{M}$ citrate buffer ( $\mathrm{pH} 4.5$ ) into the tail vein. Ten days after that, blood glucose was measured and animals with levels of $300 \mathrm{mg} / \mathrm{dL}$ or more were considered diabetic. At this time, they were submitted to a local injection of 10 microlitres of $0.1 \% \mathrm{~EB}$ (group I) or $0.9 \%$ saline (group II) solution into the cisterna pontis. All rats were anaesthetized with ketamine and xylazine $(5: 1 ; 0.1 \mathrm{ml} / 100 \mathrm{~g})$ and a burr hole was made on the right side of the skull, $8 \mathrm{~mm}$ rostral to the frontoparietal suture.

Injections were performed freehand using a Hamilton Syringe, fitted with a $35^{\circ}$ angled polished 26-gauge needle into the cisterna pontis, an enlarged subarachnoid space below the ventral surface of the pons. Nondiabetic rats also received 10 microlitres of $0.1 \% \mathrm{~EB}$ solution (group III) or $0.9 \%$ saline solution (group IV). Diabetic (group V) and non-diabetic rats (group VI) were also used without receiving any intracisternal injection (control groups).

Body weight and blood glucose levels (Dextrostix, Ames) were recorded at 3 different times - at the moment of the streptozotocin injection, 10 days after and at the time of euthanasia. Water and food were given ad libitum during the experimental period. All rats were anaesthetized; some were submitted to intracardiac perfusion with buffered 10\% formaldehyde (for immunohistochemical purpose), and some with $4 \%$ glutaraldehyde in 0.1 M Sorensen phosphate buffer $(\mathrm{pH}$ 7.4) (for transmission electron microscopy study) 15 and 31 days after intracisternal injection or not. Thin slices of the brainstem (pons and mesencephalon) were collected and post-fixed in $0.1 \%$ osmium tetroxide, dehydrated with graded acetones and embedded in Araldite 502 resin, following transitional stages in acetone. Thick sections were stained with $0.25 \%$ alkaline toluidine blue. Selected areas were trimmed, and thin sections were stained with $2 \%$ uranyl and lead acetate and viewed in a JEM -1200 EX2 JEOL transmission electron microscope.

Immunohistochemical protocol was initiated by the deparaffinization of histologic sections in xylene and re-hydration in alcohol. Endogenous peroxidase was blocked at room temperature with specific blocker Dako S2001; the material was then incubated for 30 minutes (PBS-BSA 5\%) to block unspecific proteins. Two washes with PBS were carried out between all incubations. An enzymatic process of antigenic reactivation was used to demonstrate astrocytes, employing pronase (S2013, Dako) during 15 minutes, followed by the application of rabbit anti-cow GFAP antibody (ZO334, Dako), diluted at 1:1000, for 16 hours. Sec- 
ondary goat anti-rabbit antibody (E0433, Dako) was used as the binding antibody diluted at 1:100 for 30 minutes. The material was revealed with $\mathrm{DAB}$ (diaminobenzidine) for 5 minutes and counterstained with Harris hematoxylin 1:2.

Astrocytic evaluation was done at the $3 \mathrm{I}^{\text {st }}$ day in groups I, II, III and IV using a computerized image analysis system (Image-Pro-Plus 4.5, Media Cybernetics, Silver Spring, USA), measuring by colorimetry the area stained in brown in a total area of $302,952.5 \mu \mathrm{m}^{2}$, chosen from the lesion edge, where astrocytic reaction occurred. Negative controls for immunostaining (sections lacking primary antibody application) were done. Data were analyzed by $t$ test and statistical significance was set at $\mathrm{p}<0.05$.

\section{RESULTS}

The EB-induced lesions were similar to those previously described in the brainstem of diabetic $(12,13)$ and non-diabetic rats $(2,5)$. In general terms, they were characterized by demyelinated areas in the ventral surface of the pons and mesencephalon containing, in the central region, phagocytic cells, some myelin-derived membranes in a distended extracellular space, as well as naked axons. At the periphery, the presence of oligodendrocytes and Schwann cells was noted, the latter occurring in areas of an enlarged extracellular space devoid of astrocytic prolongments, notably around blood vessels and in subpial areas. Astrocyte processes were invariably seen near the incipient, but preponderant, oligodendroglial remyelination (Figure IA and B), and Schwann cells also appeared to contribute to myelin repair. Ultrastructural analysis apparently showed that astrocytic processes among oligodendrocyte remyelinated axons were slightly thinner in diabetic animals compared with non-diabetic ones. Although oligodendroglia prevailed in the brainstem myelin repair from the $15^{\text {th }}$ to the $31^{\text {st }}$ day, sheaths formed by Schwann cells in astrocyte-free areas were thicker than those produced by oligodendrocytes during the same period. Lymphocytes and infiltrating pial cells were also observed, the first contacting phagocytic cells and myelin debris.

All rats submitted to streptozotocin injection presented hyperglycemia (levels from 300 to $650 \mathrm{mg} /$ $\mathrm{dL}$ ) at the $10^{\text {th }}$ day and at perfusion day. During the experimental period they developed characteristic polyuria, polydipsia, and weight loss (body weight data are shown in Table 1). As previously described $(12,13)$, diabetic rats from group I presented delayed macrophage activity at the $15^{\text {th }}$ and $31^{\text {st }}$ day after EB injection, as shown by the finding of huge amounts of myelin-derived membranes in the extracellular space, and a lesser extent of remyelination by both oligodendrocytes and Schwann cells at the edges of the lesions in comparison with non-diabetic rats from group III. A greater proportion of axons persisted without myelin and remyelinated ones clearly presented thinner myelin sheaths.
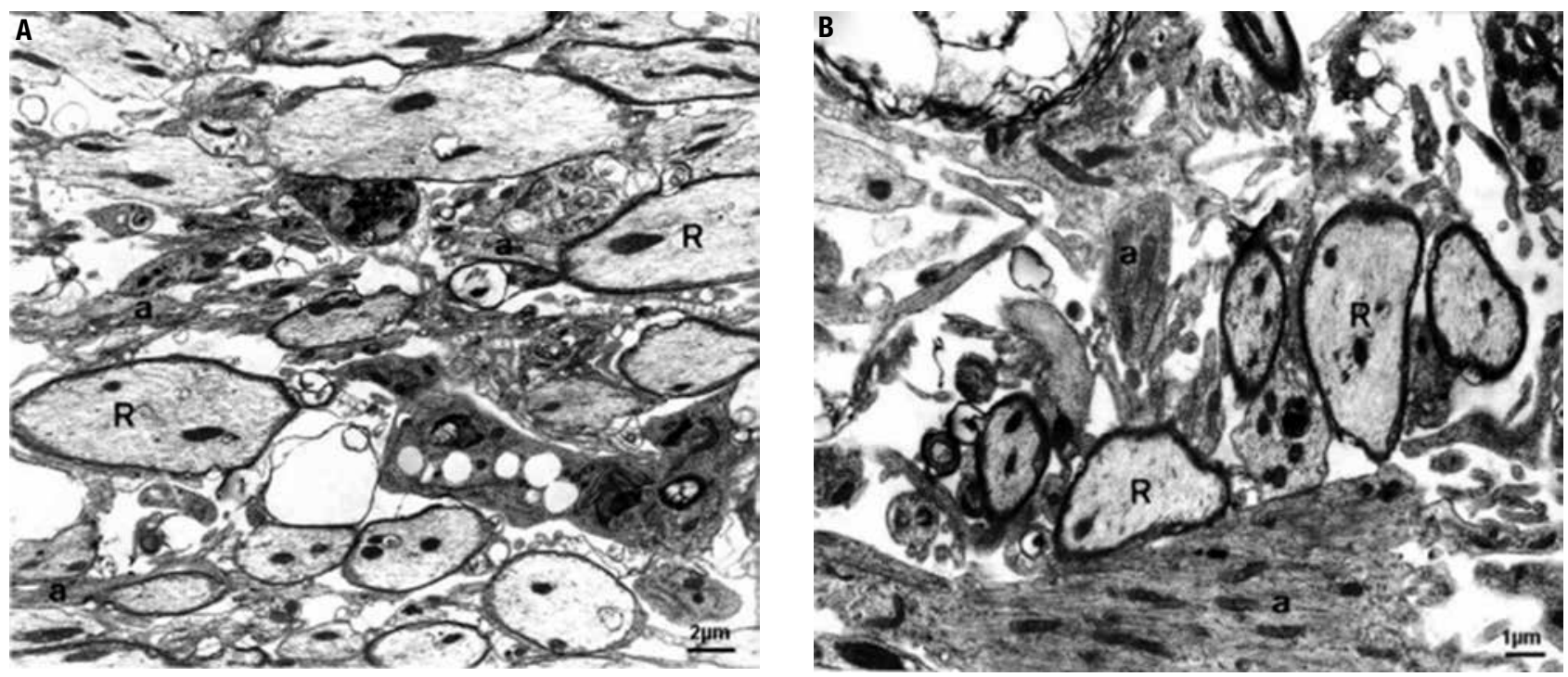

Figure 1. EB-induced lesions in groups I (A, diabetic) and III (B, non-diabetic) 15 days post-injection. Note the presence of axons in initial oligodendroglial remyelination $(\mathrm{R})$ among astrocytic processes (a). Note in $\mathrm{B}$ some hypertrophic astrocyte prolongments (a) with greater bundles of intermediate filaments Electron micrographs - A) Bar $=2 \mu \mathrm{m}$; B) Bar $=1 \mu \mathrm{m}$. 
Table 1. Body weight of the animals in the experimental groups

\begin{tabular}{|c|c|c|c|c|c|c|}
\hline & \multicolumn{3}{|c|}{ Diabetic groups } & \multicolumn{3}{|c|}{ Non-diabetic groups } \\
\hline & I-EB injection & II-Saline injection & V-Control & III-EB injection & IV-Saline injection & VI-Control \\
\hline Day -10 & (16) & (16) & (16) & (16) & (16) & (16) \\
\hline BW (g) & $271.4 \pm 8,7$ & $268.4 \pm 5.9$ & $276.5 \pm 7.7$ & $258.8 \pm 4.9$ & $265.6 \pm 3.7$ & $278.8 \pm 3.4$ \\
\hline Day 0 & (16) & (16) & (16) & (16) & (16) & (16) \\
\hline BW (g) & $268.2 \pm 6.4$ & $267.6 \pm 3.1$ & $274.5 \pm 3.6$ & $264.2 \pm 4.1$ & $278.3 \pm 2.8$ & $285.5 \pm 2.9$ \\
\hline Day 15 & (16) & (16) & (16) & (16) & (16) & (16) \\
\hline BW (g) & $256.3 \pm 7.2$ & $259.1 \pm 6.1$ & $246.3 \pm 5.5$ & $266.6 \pm 5.9$ & $286.3 \pm 4.4$ & $289.1 \pm 7.8$ \\
\hline Day 31 & (8) & (8) & (8) & (8) & (8) & (8) \\
\hline BW (g) & $238.4 \pm 8.8$ & $246.8 \pm 8.2$ & $239.3 \pm 9.3$ & $317.7 \pm 6.1$ & $328.5 \pm 4.5$ & $325.3 \pm 3.2$ \\
\hline
\end{tabular}

BW: body weight; Day-10: day of streptozotocin injection in groups I, II and III; Day 0: day of EB administration in groups I and III or day of saline administration in groups II and IV. Data are presented as means \pm standard deviations $(\mathrm{SD})$ for the number of rats given in parenthesis.

In saline-injected rats from groups II (diabetic) and IV (non-diabetic), mild lesions circumscribed to the pons and along the needle track were detected in just one animal from each group at day 15 post-injection, probably due to the surgical procedure, and no difference was noted between them. Ultrastructural analysis of these two lesions showed a small and focal expansion of the extracellular space, containing some loose lamellae and few phagocytic macrophages. No evidence of primary demyelination or loss of neuroglia was found.

EB-induced lesions presented increased astrocyte reaction close to the edges of the injury site, expressed by the finding of thickened and strongly brown-stained astrocytic processes 15 and 31 days post-injection (Figure $2 \mathrm{~A}$ and $\mathrm{B}$ ), although no astrocytes were observed in the central areas of the lesions. Astrocytic immunoreactivity following saline injection was very discrete.

In both diabetic and non-diabetic groups, GFAPstained areas at 31 days were significantly greater in EBinjected rats than in saline-injected or control animals (Table 2), but were smaller in the diabetic rats (group I, $41669.63 \pm 7204.08)$ in comparison with non-diabetic ones (III, 55354.38 $\pm 5825.37 ; \mathrm{p}=0.001$ ). As for diabetic rats compared with non-diabetic, no difference was found between control animals (groups V and VI) and saline-injected rats (groups II and IV), nor for diabetic groups II and V and non-diabetic groups IV and VI, with rats injected with saline solution or not.

\section{DISCUSSION}

Astrocytes play a key role in CNS homeostasis, including maintenance of the blood-brain barrier, neuroprotection from reactive oxygen species, regulation of neuronal activity and synaptic transmission, energy supply, as well as control of extracellular $\mathrm{pH}$ and ion and neurotransmitter concentrations, among many other functions $(14,15)$.

Intermediate filaments of astrocytes are composed mainly of GFAP, and this protein has become the best known astrocytic marker (15-17). Intermediate filaments are one of the three components of cytoskeleton and the term "intermediate" reflects their thickness (about $10 \mathrm{~nm}$ ) which falls between the thickness of the other two cytoskeletal components - actin filaments
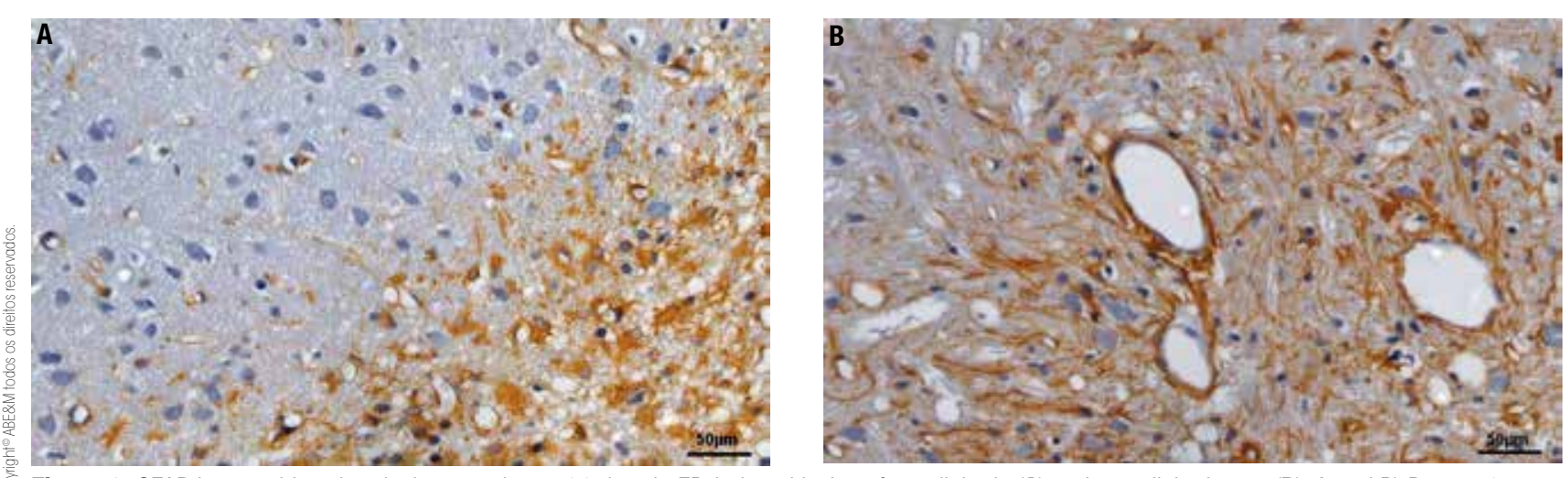

Figure 2. GFAP immunohistochemical expression at 31 days in EB-induced lesions from diabetic (A) and non-diabetic rats (B). $A$ and $B) B a r=50 \mu m$. 
Table 2. Areas with GFAP staining in $\mu \mathrm{m}^{2}$ in a total area of $302,952.5 \mu \mathrm{m}^{2}$ at 31 days, in rats diabetic or not, injected with EB or not

\begin{tabular}{|c|c|c|c|c|c|c|}
\hline \multirow[b]{2}{*}{ Animal } & \multicolumn{3}{|c|}{ Diabetic groups } & \multicolumn{3}{|c|}{ Non-diabetic groups } \\
\hline & $\begin{array}{l}\text { I-EB injection } \\
\left(\mu \mathrm{m}^{2}\right)\end{array}$ & $\begin{array}{c}\text { II-Saline injection } \\
\left(\mu \mathrm{m}^{2}\right)\end{array}$ & $\begin{array}{c}\text { V-Control } \\
\left(\mu \mathrm{m}^{2}\right)\end{array}$ & $\begin{array}{l}\text { III-EB injection } \\
\left(\mu \mathrm{m}^{2}\right)\end{array}$ & $\begin{array}{c}\text { IV-Saline injection } \\
\left(\mu \mathrm{m}^{2}\right)\end{array}$ & $\begin{array}{c}\text { VI-Control } \\
\left(\mu \mathrm{m}^{2}\right)\end{array}$ \\
\hline 1 & 50,241 & 5,834 & 9,313 & 47,281 & 6,132 & 6,249 \\
\hline 2 & 60,312 & 10,105 & 8,131 & 39,522 & 5,041 & 8,833 \\
\hline 3 & 48,154 & 4,581 & 5,121 & 51,430 & 4,190 & 5,214 \\
\hline 4 & 53,826 & 6,912 & 4,297 & 40,265 & 7,013 & 5,575 \\
\hline 5 & 57,115 & 6,134 & 5,642 & 34,127 & 7,264 & 7,266 \\
\hline 6 & 61,232 & 7,283 & 6,715 & 36,112 & 6,145 & 4,127 \\
\hline 7 & 62,841 & 8,145 & 4,237 & 50,717 & 4,827 & 4,483 \\
\hline 8 & 49,114 & 4,905 & 8,541 & 33,903 & 8,549 & 9,028 \\
\hline Mean & $55,354.38^{a}$ & $6,737.38^{c}$ & $6,499.6^{c}$ & $41,669.63^{b}$ & $6,145.13^{c}$ & $6,346.88^{c}$ \\
\hline standard deviation (SD) & $\pm 5,825.36$ & $\pm 1,806.27$ & $\pm 1,978.4$ & $\pm 7,204.08$ & $\pm 1,442.37$ & $\pm 1,871.01$ \\
\hline
\end{tabular}

Distinct letters indicate significant differences $(p<0.05)$.

(about $6 \mathrm{~nm}$ ) and microtubules (about $23 \mathrm{~nm}$ ). In contrast to microtubules and actin filaments, the composition of intermediate filaments changes among cell types, their developmental stages, and functional status (16). Astrocyte precursors and immature astrocytes present principally nestin and vimentin and, as astrocytes mature, nestin expression disappears, GFAP becomes increasingly expressed, and vimentin decreases to undetectable levels (15).

Insults to the CNS, such as trauma, ischemia, tumors, neuroinflammation, and neurodegenerative disorders lead to astrocytic activation, also known as reactive gliosis or astrogliosis, increasing the production of intermediate filaments. In such conditions, reactive astrocytes become highly positive for GFAP and vimentin, also reexpressing the third filament protein, nestin (14-16). Reexpression of vimentin and strong astrocytic immunoreactivity to GFAP were clearly seen by Bondan and cols. (5) following EB injection in the rat brainstem from the $3^{\text {rd }}$ to the $3 \mathrm{I}^{\text {st }}$ day post-gliotoxic injection.

This increased GFAP expression around the EB-induced lesions was also confirmed in the present study, but it was noted in the streptozotocin-diabetic rats that somehow diabetes hindered the increase in this expression, although the same was not observed after saline solution injection. Besides, diabetic rats that did not receive any intracisternal injection (EB or saline; control group) had no significant difference in GFAP expression from non-diabetic ones, suggesting that such difference caused by the diabetic status was only detected when a strong glial response to injury was induced (5).
Meanwhile, decreased astrocyte GFAP expression in type 1 diabetic rats was also found by other researchers with no additional harmful condition beyond diabetes $(11,18-22)$. On the other hand, insulin treatment has shown to prevent diabetes-induced decreases in astrocytic GFAP content (11)

Although astrocytes were not individually counted in our study, the decrease in GFAP content seen in diabetic rats apparently reflected a decrease in GFAP expression rather than a decrease in the number of astrocytes. This observation is similar to that of Coleman and cols. (11), and differs from Lechuga-Sancho and cols. (21), who reported a decrease in rat hypothalamic astrocyte numbers after 6 weeks of diabetes onset. It is recognized that astrocyte counts based on quantifications of GFAP-positive cells are not really representative, as diminution of GFAP immunoreactivity could lead to undercounting.

While it was initially thought that astrocyte proliferation was a major component of glial scar, it has been demonstrated repeatedly that there are actually few astrocytes undergoing cell division during gliosis (17). To corroborate this affirmation it is important to notice that no astrocyte in mitotic activity was seen in our studies, with astrocytic response following gliotoxic lesions $(4,5)$.

The association of reactive astrocytes with enhanced GFAP and cellular hypertrophy, coupled with the in vitro observations that mature astrocytes do not represent a supportive environment for axon growth, has led to a widespread concept that reactive astrocytes are always detrimental to regeneration in the CNS. However, it 
has been proved in several models of brain and spinal cord injury that not all reactive astrocytes produce nonpermissive molecules for neural regeneration, such as tenascin and condroitin sulfate family of proteoglycans, which are inhibitory for neurite outgrowth (17). In opposition to this proteoglycan up-regulation associated with regenerative failure in vivo, reactive astrocytes also produce molecules that can support regeneration, such as laminin (17). In addition, astrocytes are recognized to support oligodendrocytes during myelination and remyelination (15), and this role is particularly important after myelin loss due to naturally occurring or experimentally induced demyelinating processes, such as the EB gliotoxic model.

The reaction of astrocytes following trauma forming a glial scar surrounding the area of lesion could wall off the damaged area in an attempt to isolate the injury site and prevent any further damage to the nearby tissue, which is still viable.

Decreases in GFAP expression are invariably associated with detrimental conditions in the CNS (23) and this was also expected in relation to diabetes. Due to the complex scenario of CNS repair, the ambiguous roles of astrocytes in nervous tissue remodeling after injury, and as diabetes apparently negatively affects astrocyte reaction, it is difficult to precisely infer if this impaired astrocytic response would play a beneficial or a deleterious influence on the restoration of morphological and functional tissue integrity after neural damage.

Acknowledgements: this study was supported by São Paulo Research Foundation (Fapesp - 2008/58696-2) and National Counsel of Technological and Scientific Development (CNPq).

Disclosure: no potential conflict of interest relevant to this article was reported.

\section{REFERENCES}

1. Graça DL, Bondan EF, Pereira LAVD, Fernandes CG, Maiorka PC. Behaviour of oligodendrocytes and Schwann cells in an experimental model of toxic demyelination of the central nervous system. Arq Neuropsiquiatr. 2001;59:358-61.

2. Pereira LAVD, Dertkigill MS, Graça DL, Cruz-Höffling MA. Dynamics of remyelination in the brain of adult rats after exposure to ethidium bromide. J Submicrosc Cytol Pathol. 1998;30:341-8.

3. Bondan EF, Lallo MA, Sinhorini IL, Pereira LAVD, Graça DL. The effect of cyclophosphamide on the rat brainstem remyelination following local ethidium bromide injection in Wistar rats. J Submicrosc Cytol Pathol. 2000;32:603-12.

4. Bondan EF, Lallo MA, Dagli MLZ, Pereira LAVD, Graça DL. Blood-brain barrier breakdown following gliotoxic drug injection in the brainstem of Wistar rats. Arq Neuropsiquiatr. 2002;60:582-9.
5. Bondan EF, Lallo MA, Dagli MLZ, Sanchez M, Graça DL. Investigation into the astrocytic immunoreactivity to GFAP and vimentin in the brainstem of Wistar rats submitted to the ethidium bromide gliotoxic model. Arq Neuropsiquiatr. 2003;61:642-9.

6. Vincent AM, Kato K, McLean LL, Soules ME, Feldman EL. Sensory neurons and Schwann cells respond to oxidative stress by increasing antioxidant defense mechanisms. Antioxid Redox Signal. 2009;11:425-38.

7. Li $P$, Ding $C$, Muranyi $M, H e$, Lin Y. Diabetes mellitus causes astrocyte damage after ischemia and reperfusion injury. J Cereb Flow Metab. 2005;25:S430.

8. Muranyi M, Ding C, He Q, Lin Y, Li P. Streptozotocin-induced diabetes causes astrocyte death after ischemia and reperfusion injury. Diabetes. 2006;55:349-55.

9. Li PA, Siesjo BK. Role of hyperglycaemia-related acidosis in ischaemic brain damage. Acta Physiol Scand. 1997;161:567-80.

10. Li PA, Gisselsson L, Keuker J, Vogel J, Smith MI, Kuschinsky W, et al. Hyperglycemia exaggerated ischemic brain damage following $30 \mathrm{~min}$ of middle cerebral artery occlusion due to capillary obstruction. Brain Res. 1998;804:36-44.

11. Coleman ES, Dennis JC, Braden TD, Judd RL, Posner P. Insulin treatment prevents diabetes-induced alterations in astrocyte glutamate uptake and GFAP content in rats at 4 and 8 weeks of diabetes duration. Brain Res. 2010;8:131-41.

12. Bondan EF, Lallo MA, Trigueiro AH, Ribeiro CP, Sinhorini IL, Graça DL. Delayed Schwann cell and oligodendrocyte remyelination after ethidium bromide injection in the brainstem of Wistar rats submitted to streptozotocin diabetogenic treatment. Braz J Med Biol Res. 2006;39:637-46.

13. Bondan EF, Martins MFM. Blood-brain barrier breakdown and repair following gliotoxic drug injection in the brainstem of streptozotocin-diabetic rats. Arq Neuropsiquiatr. 2012;70:221-5.

14. Ramos AT, Viott AM, Machado GF. Astrócitos. In: Graça DL, Bondan EF, Pereira LAV, Maiorka PC (eds.). Biologia da desmielinização e da remielinização: a base da esclerose múltipla. Santa Maria: Editora UFSM; 2011. p. 35-59.

15. Sofroniew MV, Vinters HV. Astrocytes: biology and pathology. Acta Neuropathol. 2010;119:7-35.

16. Pekny M. Astrocytic intermediate filaments: lessons from GFAP and vimentin knock-out mice. In: Castellano-López B, Nieto-Sampedro M. Glial cell function. Amsterdam: Elsevier; 2001. p. 22-30.

17. Fitch MT, Silver J. Astrocytes are dynamic participants in central nervous system development and injury responses. In: Jessen KR, Richardson WD. Glial cell development. Oxford: Oxford University Press; 2001. p. 263-77.

18. Barber AJ, Antonetti DA, Gardnes TW. Altered expression of retinal occludin and glial fibrillary acidic protein in experimental diabetes. Invest Ofthalmol Vis Sci. 2000;41:3561-8.

19. Coleman ES, Judd R, Hoe L, Dennis J, Posner P. Effects of diabetes on astrocyte GFAP and glutamate transporters in the CNS. Glia. 2004;48:166-78.

20. Dennis JC, Coleman ES, Swyers SE, Moody SW, Wright JC, Judd $\mathrm{R}$, et al. Changes in mitotic rate and GFAP expression in the primary olfactory axis of streptozotocin-induced diabetic rats. $J$ Neurocytol. 2005;34:3-10.

21. Lechuga-Sancho AM, Arroba Al, Frago LM, Garcia-Cáceres C, de Célix AD, Argente J, et al. Reduction in the number of astrocytes and their projections in association with increased synaptic protein density in the rat hypothalamus of poorly controlled diabetic rats. Endrocrinol. 2006;147:5314-24.

22. Afsari $Z H$, Renno WM, Abd-El Basset E. Alterations of glial fibrillary acidic proteins immunoreactivity in astrocyte of the spinal cord diabetic rats. Anat Rec. 2008;291:390-9.

23. Pekny M, Pekna A. Astrocyte intermediate filaments in CNS pathologies and regeneration. J Pathol. 2004;204:428-37. 